\title{
Collectivization, participation and dissidence on the transatlantic axis during the Cold War: Cultural Guerrilla for destabilizing the balance of power in the 1960s
}

\author{
Paula Barreiro López \\ Facultat de Geografia i Història, Montalegre, 6, 08001 Barcelona, Universitat de Barcelona \\ e-mail: paula.barreiro@ub.edu
}

Submitted: 21 September 2015. Accepted: 8 February 2015

\begin{abstract}
This article analyses the role of collectivization and participation and their configuration under the concept of Cultural Guerrilla that implied a socio-political commitment of artists in the 1960s. It discusses how the Cultural Guerrilla was understood by the artists and how it participated in the destabilization of the social (and political) system and in confronting the imperialist policies of the US. It, firstly, focuses on the development processes of a collective and participative action during that decade and its role for confronting the aesthetic model that was fostered by the US within their Cold War cultural politics. Secondly, the text approaches the exchanges of French-based artists and intellectuals with the revolutionary government of Cuba in 1967 during the organization of the Salón de Mayo in Havana, discussing, thirdly, their impact on the artists' participation during the events of May'68 in Paris.
\end{abstract}

KEYWORDS: artistic activism; May'68; art and politics; Cuban revolution; Salón de Mayo; Salon de la Jeune Peinture; Julio Le Parc; Eduardo Arroyo

Citation / Cómo citar este artículo: Barreiro López, Paula (2015). "Collectivization, participation and dissidence on the transatlantic axis during the Cold War: Cultural Guerrilla for destabilizing the balance of power in the 1960s". Culture \& History Digital Journal, 4 (1): e007. doi: http://dx.doi.org/10.3989/chdj.2015.007

RESUMEN: Colectivización, participación y disidencia en el eje trasatlántico durante la Guerra Fría: guerrilla cultural para desestabilizar el equilibrio de poder en los años sesenta.- Este artículo analiza el papel que la colectivización y la participación tuvieron en la configuración del concepto de Guerrilla Cultural, el cual implicó el compromiso socio-político del artista en los años sesenta. Se estudia el modo en el que fue entendida dicha Guerrilla Cultural por los artistas y como, a partir de la misma, participaron en la desestabilización del sistema social (y político) y en la confrontación con las políticas imperialistas de los Estados Unidos. En primer lugar, se estudia el desarrollo de los procesos de acción colectiva y participativa durante los años sesenta y su rol en el cuestionamiento del canon estético apoyado por los EEUU en sus políticas culturales durante la Guerra Fría. En segundo lugar, el artículo analiza los intercambios entre artistas e intelectuales residentes en Francia con el gobierno revolucionario cubano en 1967, durante la organización del Salón de Mayo en la Habana, tratando, finalmente, su impacto en los artistas que participaron en las revueltas de Mayo del 68 en París.

PALABRAS CLAVE: activismo artístico; Mayo del 68; arte y política; revolución cubana; Salón de Mayo; Salon de la Jeune Peinture; Julio Le Parc; Eduardo Arroyo

Copyright: (C) 2015 CSIC This is an open-access article distributed under the terms of the Creative Commons AttributionNon Commercial (by-nc) Spain 3.0 License. 
Apainting is an instrument of war, to be used for attacking and defending (Picasso, 1967: 1) ${ }^{1}$

In 1968 in his manifesto "Cultural Guerrilla Warfare?", the Argentinean artist Julio Le Parc declared: "I think that one must act. Act at every opportunity. Act to create other situations where we can develop a more concerted, more orchestrated action. Act even at the risk of being mistaken" (Le Parc, 1968a: 229). These words describe well one of the main principles in the arts during the second half of the 1960s: action in the artistic sphere as well as in the social one.

Le Parc baptized such "orchestrated action" —not accidentally - Cultural Guerrilla, directly referring to a well-known type of warfare employed in specific contexts during the Cold War. Guerrilla strategies had been used to counterattack the imperialist and institutional power(s) since the end of War World II. Nevertheless, the Vietcong [NFL] actions during the Vietnam War (19591975), as well as the Cuban Revolution, provided for the artists, intellectuals and citizens of the 1960s the most recent examples. They had shown that tactics such as sabotage, ambushes or raids could have a decisive impact on fighting traditionally organized, larger and militarily superior troops - and that they were quite effective for confronting the US hegemony and destabilizing the balance of power during the Cold War. In that sense, the existence of Cuba's revolutionary and socialist government in the core of the Americas as well as the uncrushed resistance of the Vietnamese people for more than 10 years were considered the proof of such results.

Empathizing strongly with the fight of an inferior opponent against the (seemingly) all-mighty forces of the (neo-) imperialist establishment, it is no wonder that artists felt compelled to adopt and re-interpret those tactics in the highly politicized and activist moment of ' 68 . Introducing them in the respective socio-cultural contexts, this Cultural Guerrilla was understood in Europe and Latin America as a way for destabilizing the cultural and social system, comprising artistic action as a part of a general revolutionary process against Imperialism. It gathered a number of artistic practices that were greatly shaped by collectivization, participation and action in the socio-political sphere. These three aspects had been closely linked and developed in the artistic scene of the 1960 s, becoming popular and eventually generalized during the riots of Paris in May' 68.

This article will analyse the role of collectivization and participation and their configuration under the concept of Cultural Guerrilla that implied a socio-political commitment of the artist in the 1960s. ${ }^{2}$ It, firstly, focuses on the development processes of a collective and participative action during that decade and its role for confronting the aesthetic model that was fostered by the US within their Cold War cultural politics. Secondly, the text approaches the exchanges of French-based artists and intellectuals with the revolutionary government of Cuba in 1967 during the organization of the Salón de Mayo in Havana, discussing, thirdly, their impact on the artists' par- ticipation during the events of May '68 in Paris. With the aim of dislocating the hegemonic Paris-New York axis, I would like to argue that the "Cuban connection" developed actively by artists and intellectuals was a determinant experience to conceive the idea of a Cultural Guerrilla that - gathering the ambitions of a more and more committed avant-garde - consciously subverted the (apparent static) division between the Western and Eastern models, which shaped the Cold War.

\section{COLLECTIVIZATION AND PARTICIPATION: DESTABILIZING THE INDIVIDUAL}

When Le Parc published his manifesto, the climate of conflict and dissatisfaction in the Western world was about to burst with contestants taking over the streets of Paris, Washington, Madrid, Buenos Aires or Mexico. During the riots in Paris, artists would seek collaboration with workers and students. Their organization in action groups as well as a collective production would eventually become essential parts of the participation in the protests movement(s). ${ }^{3}$ In May'68, collective artistic actions were chosen and developed further, consciously annihilating the traces of the individual artist. Collectivization as "modus operandi" was clearly considered most effective for the joint purpose of attacking the establishment and, following Le Parc's words, for "attempting to overthrow the established values at the heart of the art world" (Le Parc, 1968b: 149). Consequently, the artists took the idea of collectivization further by actively participating in the strikes, barricades and resistance actions throughout the city. This way they would play determinant roles, as for example in the occupation of the École Nationale de Beaux Arts and the creation there of the famous Ateliers Populaires (Popular Workshops) where most of the supportive posters that would cover many walls in the city during the strikes were collectively produced; or in the occupation of the Maison d'Argentine and other houses at the Cité Internationale Universitaire de Paris during the months of May and June 1968 (Barreiro-López, 2009b).

Actually, this kind of collectivization and political activism became one of the most urgent issues for artists in 1968. Nevertheless, even though they manifested most clearly at that moment, such convictions were not new and their roots went deeper. They were the result of a continuous process of reconfiguration of the artistic bases and modes of production since the end of the 1950s, developed within the socio-political and cultural framework that was being crafted by the superpowers of the Cold War. In this context, collectivization did not just offer new possibilities of artistic production, but had operated within leftist circles in Europe and Latin America as a counter-model to the individual, existential and autonomous conceptions that underpinned the official US rhetoric of modern art (Galimberti, 2013). The configuration of that narrative, which based modernism on the individual and subjective production of the artist and coped with political, ideological and cultural aims of the USA (shared 
within the Western block) had been instrumentalized consequently by its apparatus for winning cultural and ideological hegemony (Guilbaut, 1983: 141). It had become strongly present since the end of World War II, then clearly being politicized in the heat of the Cold War in which US and USSR models were confronted. In this context, "individual" as well as "collective" to a large extent became associated with those two political, intellectual and cultural systems and naturally opposed.

The identification of the individual, expressive and autonomous conception of modern art was most clearly expressed in the US with the movement of Abstract Expressionism (and in Europe with the "informel"). The latter could be conveniently turned into a "weapon of the Cold War", as North American artists and intellectuals such as Eva Cockcroft (1985) had noticed. Other scholars have demonstrated the intimate connections established between Abstract Expressionism and the corporate and political ideas of the US government, retrieving not just the cultural politics and the participation of intellectual, cultural and political institutions in the championing of the gestural abstract expressionist canvases, but also pointing out the main agents and their cultural, social, artistic and economic interests (Guilbaut, 1983, 2007; Stonors Saunders, 2000). After all, not by chance was the mighty director of the Museum of Modern Art, Alfred Barr in 1949 comparing Abstract Expressionism with the free-market politics of the US (Barr quoted in Guilbaut, 2007: 46).

The relation between the aesthetic basis of an individual, subjective and existential production and the neoliberal and imperialist political model of the West was not just evident for artists and scholars from 1970 onwards, but had already been felt during the years of Abstract Expressionist hegemony (and its European counterpart, the informel). Several artists, art critics and intellectuals started to dissociate from the framework of an individualistic conception of modern art firmly established in the West. Looking for alternatives, they felt the urge to seek out collective production processes associated with social concerns. Hence, collectivism increasingly mapped the artistic scene of the late 1950s and 1960s, opening a path that would lead to the collective and direct participation of artists in the streets of May 1968. If in 1957 Guy Debord was considering collective work for revolutionizing the everyday life, at the same time the Spanish team Equipo 57 was calling for a "collective solution as a point of departure" via an integral and international organization of "large teams of plastic artists, architects, sculptors, painters from all countries in the world" (Equipo 57, 1993: 156).

Two years later, Julio Le Parc along with a group of artists from Argentina, Spain and France (Horacio García Rossi, Francisco Sobrino, Jean-Pierre Yvaral, Jöel Stein and François Morellet) founded the Groupe de Recherche d'Art Visuel (GRAV), aiming for a collective production and the demystification of the artwork (Aupetitallot, 1998). The choice of Equipo 57 and GRAV for geometrical abstraction and rationality aimed to dismiss the bourgeois thought that seemed intimately linked with the praise of irrationalism and existentialism underpinning the individualistic production in the Western Block - coping therein with Lukàc's denunciation of the continuities between Fascism and post-war irrationalism in his work The Destruction of Reason (Galimberti, 2013: 86).

Their aims were in fact part of a general interest that manifested from the late 1950s all along Western Europe and Latin America. In the transatlantic axis (from Spain to Argentina and from France to Zagreb), collectivization and rationalization of artistic production (via the recuperation of the Concrete Art legacy) became a more common phenomenon considered in direct opposition to the exaltation of the individual and subjective action that abstract expressionists and informel artists praised (BarreiroLópez, 2009a). The creation of other artists' collectives, such as N (Padua), T (Milan), Madí (Buenos Aires) and Equipo Córdoba (Córdoba), showed - despite their differences - a new path that connected to GRAV's aims, implying a dismissal of the individual that, in Equipo Córdoba's words, "constitutes a force that [...] delays the advance of society" (Escuela Experimental de Córdoba, 1957: 22). ${ }^{4}$

The gathering of most of those artist teams in the movement Nouvelle Tendance (New Tendency) from 1961 onwards manifested the growing interest for a communitarian and transnational action, overcoming the imposed boundaries of the Cold War geographies (Hofmann, 2007; Medosch, 2012). In fact, this transnational artistic network was founded in 1961 in Zagreb (with its first exhibition at the Gradska galerija suvremene umjetnosti) and had associated members in several cities in East and West Europe as well as Latin America. They were mainly interested in geometrical abstraction, visual perception and optical illusions. Nouvelle Tendance was proposing a kind of "non-aligned" modernism, integrating in some way the disconformity with the Cold War division of the world that had already been institutionalized the same year at the Conference of the Heads of State or Governments of the Non-Aligned Countries in Belgrade. ${ }^{5}$ Actually, this disconformity had been present previously in the discussions of some of those artistic teams. In 1957, in their first manifesto, the members of Equipo 57 had expressed the confrontation between West and East, opting for an independent path that could contest the binary opposition imposed upon the citizens of the Cold War world, stating:

today the artist finds himself caught between two sociopolitical currents - communism and the bourgeoisieeach of them demands that he serves its respective cause. In such circumstances he must fight for his independence and for his historical significance, aware that religious, political and moral power emanates from esthetic power (Equipo 57, 1993: 154).

The gathering of artists in collective working processes determined not just the endorsement of a communitarian project, but also an ambition to reconnect with the so- 
cial praxis and the working class-aims that had roots in a revision of Marxist thought. Even if connections between these groups and Communist political factions existed (as was the case, for example, for some Equipo 57 members), their relation was at odds with the Soviet Communist Party guidelines - reverberated in their own countries by the Communist Party - due to its strong dismissal of abstract art as bourgeois and decadent and its support of Socialist Realism. Instead, they favoured a revised Western Marxism that coped with the ideas of the New Left and that had its origins in the Soviet Union's violent dismantling of the Hungarian revolution in 1956 and the subsequent disenchantment of the Western leftists; or as Gruppo N with the Italian revolutionary movement of Operaisti (Galimberti, 2012). For example, François Morellet, one of the artists belonging to the ephemeral collective Motus (which would eventually expand into GRAV), explained that the "confidence in reason, progress and its suspicion towards individualism seemed to us capable (I hope this does not bother Zhanov) of responding to the wishes of true Marxism" (Morellet quoted in Galimberti, 2013: 85). In the cases of other artists, the connections with this Marxist lineage are less visible, even though their work was clearly shaped by social aims. For example, in the 1964 Nouvelle Tendance exhibition at the Musée des Arts Décoratives of Paris, the Swiss artist Karl Gerstner felt compelled to clarify: "some of us would like to describe [our art] as socialist. It is, in any case social" (K.G., 1964). ${ }^{6}$

Following the promising paths given by Russian constructivism and the Bauhaus, artistic groups in Europe and Latin America intended to re-integrate their work in the social space via collective, rational and constructivist means. If the association between geometrical abstraction and social(ist) aspirations were already present in circles around Tomás Maldonado, Raul Loz$\mathrm{za}$, the artists of Arte Concreto Invención, or Gyula Kosice and Madí in Buenos Aires in the 1940s (Hillings, 2004; Longoni and Lucena, 2004), they eventually also entered the debates on the other side of the Atlantic. For example, they became more and more visible from the early years of the 1960s onwards in the thoughts of Equipo 57 and the Arte Normativo movement (in Spain), as well as in those of New Tendencies or the debates during the Biennial of San Marino and Rimini's Convegno di artisti, critici e studiosi dell'arte in 1963 (Barreiro-López, 2009c).

In those discussions, collective production was endorsed as a positive feature that went further than a transformation of the artistic means of production. Giulio Carlo Argan, professor of Art History at the University La Sapienza in Rome and president of the "Convegno", was one of the strongest supporters of collectivism and was responsible for establishing a direct link between artistic production and political organization. In a series of articles published in the Italian journal Il Messagero during summer 1963, he warned about the implications that "individual" and "collective" concepts had for the entire configuration of the social world:
Those who want to defend the individual's free activity from the $[\ldots]$ inertia of the masses should remember that the fundamental quality of the person is the capability $[\ldots]$ of teaming up $[\ldots]$ and associating with others for a shared goal. It should not be forgotten that the masses, and those who direct and exploit them, are always indulgent and even generous with the solitary man, even when he is a rebel. By contrast, they fear the group $[\ldots]$ and despise the organized community [...] [The masses] are always capable of generating [...] a monstrous type of "individual", of "unique being", the dictator (Argan quoted in Galimberti, 2013: 133).

The polemic claims of those articles provoked an uproar in intellectual and artistic circles in Italy (Celant, 1981: 107-108) and, at the same time, proved until which point the choice of collectivism was politically positioned; a chance that was quickly perceived by some of the participants at the conference of Rimini - for example, Eduardo Arroyo.

Since 1963, this Paris-based Spanish painter had been considering the possibilities of collective action. He was well aware of the collectivist aims already developed by his contemporaries as he had been visiting and debating with the members of Equipo 57 in their Parisian atelier (Ameline, 2008: 283). Working together with the Frenchman Gilles Aillaud and the Italian Antonio Recalcati (with the collaboration of Francis Biras, Fabio Riéti and Gérard Fromanger), they directed a first critique toward the artistic institution and individual genius (represented clearly by the figure of Marcel Duchamp determinant for the French and North American neo-avant-garde artists of the mid 1960s). With the irreverent painting Vivre et laisser mourir ou la fin tragique de Marcel Duchamp (Live and Let Die or The Tragic End of Marcel Duchamp), painted in 1965, they depicted the assassination of this key artist for the neoavant-garde movements (at that time still alive) and presented an "emblem of anti-Americanism" that counteracted the US's ideological, economic and political power (Carrick, 2008: 14). At the same time, they positioned themselves against what Recalcati called "Stalinist conformism", as the painting's figurative language did not remotely submit to Socialist Realism (Recalcati quoted in Carrick, 2008: 13). Soon afterwards in 1966, when these artists took control of the Salon de la Jeune Peinture in Paris (Gilles Aillaud became its President, Eduardo Arroyo the Secretary and Antonio Recalcati a Jury Member), they started to spread their ideas via this critical platform (Parent and Perret, 1983). Actually, the convictions of the Salon de la Jeune Peinture's artists (many of them members of the recently born movement of Figuration Narrative) regarding the necessity of collective action - despite the obvious differences concerning aesthetic choices - were not so far from those of Le Parc; this is not surprising, as Julio Le Parc and Antonio Berni (a participant of Figuration Narrative) had shared a studio until 1968 (Plante, 2011: 64). In the end, this view on collectivization that had irradiated the vanguard scene by then would determine the artists' ac- 
tive commitment with the May revolts of '68, including Le Parc as well as the artists of the Salon de la Jeune Peinture.

Along with the imagined positive outcomes of collectivization for the whole social order, the Convegno of Rimini in 1963 touched the increasing interest in the implication of the viewer in the creative processes that the teaming up had entailed. GRAV had made the transformation of the spectator into a participant of the artwork's development and experience one of its crucial interests. This issue should promptly acquire a larger dimension when connected to the social aspirations creating the expectance of achieving a social awakening through the participation of the spectator. Following this idea, the ambitious intention was to show the possibility of destabilizing the artistic and social structure by implicating the spectator. As the artists of GRAV wrote: "We want to free the spectator from the apathetic reliance which makes him passively accept not only what is forced upon him as art, but a whole system of life as well" (GRAV, 1963: 127). The Labyrinth and the Columns that the group presented at the Biennial of Paris in 1963 (in a section specially conceived for collective projects) seemed to respond to this claim. A series of ludic ambiences, mirrors and gadgets invited interaction inside the labyrinth. When the visitors left this space, they would be confronted with white and black columns on wheels. These hollow structures, each equipped with a door, could be entered and moved around by everybody, thus leading to situations that the visitors would often meet moving columns when leaving the labyrinth. This transformable and manipulable installation, seemed to suggest that "the structural elements of society are given only apparently" (Galimberti, 2013: 95), pointing out the value of each participant in the social space.

Such issues would become fundamental during 1968. So if in 1966 GRAV confronted Parisian pedestrians with artistic artefacts in the streets during their action called Une journée à la rue, two years later - around the time when the group was about to dissolve - Le Parc refocused the social interests on the phenomenon of participation that had guided GRAV's work and expressed a clearer political aim. In his essay "Cultural Guerrilla Warfare?", he stated that the consideration of the spectator in the artistic field was the first step to a general participation of individuals in the social and political context. For him "the role of the intellectual and the artists in society" was committed to the social change, by showing "the contradictions existing in each milieu" and developing "actions so that the people themselves produce the changes" (Le Parc, 1968a: 230).

Considering the associations that artists and art critics were making between artistic practices and social system, it is not surprising that collectivism was regarded with suspicion in specific socio-political contexts, thereby proving its potential to disturb the established order and the conceptual configuration of an alternative basis for modern art. For example, in Francoist Spain, Equipo 57's fierce support of collectivism was not just an attempt to challenge the exaltation of the individual regarding the arts, but implicitly contested the strict control and repressive measures that the regime had put upon Spanish society regarding collective actions (Galimberti, 2013: 65). Its collective working practice consequently played an important role in the rejection of direct support by José Luis González Robles, the official curator of the Spanish pavilion at the Biennials of Venice and Sao Paulo (from 1957 to 1972), to exhibit at the Sao Paulo Biennial of 1961 (Barreiro-López, 2003: 132-134). ${ }^{7}$ When collectivism associated itself with a critical figurative language, the reactions were even more radical. At the 1963 Paris Biennial (where GRAV presented its Labyrinth) one of the installations was the work of the group L'abattoir (Eduardo Arroyo, Mark Biass, Mark Brusse, Jorge Camacho and Pierre Pinoncelli). Part of its collective work was a set of four paintings entitled Les quatre dictateurs (The four dictators) by Eduardo Arroyo, which was censored for its "offensive" character. The representation of Franco, Salazar, Hitler and Mussolini (four half-portraits with sliced-open bodies showing their internal organs, identifiable by the respective country flags taken as backgrounds) denounced clearly the political survival of dictatorships in Europe and the explicit collaboration of the (Western) "free and democratic world" with them. The Biennial organizers found themselves in a delicate situation, as the paintings had the actual power to compromise the diplomatic relationship between France and Francoist Spain (Gassiot-Talabot, 1982: 9). ${ }^{8}$ In this situation they decided to have the national colours of the paintings covered with black sheets. However, even though the identification of the portraits was less possible afterwards, this proved the potential of paintings to criticize and even seriously worry the institutional and political powers.

By the second half of the 1960s, the phenomenon of collectivization became quite general in the European artistic scene, becoming a consciously used tool for dissidence in a climate that became more and more belligerent. In 1966 the Maoist journal Opposition Artistique - published by the Parisian art dealer Suzanne Bernard, who briefly opened an exhibition space (the Galerie Socio-Expérimentale, where GRAV and also Arroyo exhibited) - argued for a collective and political activism directed against the hegemonic powers of the West. Conveying thus the underlying message of May '68, the journal also pointed out "the necessity of engaging in combat" - a conviction that inevitably grew with the increasing confrontation - emphasizing furthermore that "the moment has come to structure these oppositions, to unite our forces to make an international front of cultural and artistic opposition" (quoted in Scott 2010: 86).

\section{CLOSING THE RANKS: FOR CUBA AND THE "LATIN AMERICAN CAUSE"}

Actually, the imagery of the Third World and its political agency became an important issue within the above-depicted processes, helping to configure the kind of revolutionary movement that Opposition Artistique 
had been evoking in 1966. For example, Le Parc's call to action and participation in 1968 was in fact directly connected to his growing identification with the situation in Latin America. Born and trained in Argentina, he had moved to Paris in 1957, during the following decade becoming increasingly involved with Latin American intellectual and political movements that gave importance to "the social role of the intellectual", sensitizing him for the "Latin American cause" (Plante, 2011: 164). The demands for an implicated participation in society that his pamphlet "Cultural Guerrilla Warfare?" presented were in fact a direct result of his own experiences in different South American countries as he would state:

\begin{abstract}
After spending four months in a number of South American towns (Buenos Aires, Mendoza, Sao Paulo, Valencia, Caracas) and attending the Symposium of American Intellectuals and Artists at Puerto Azul (Venezuela) in November 1967 ... I felt, when I got back to Paris, the need to clarify and reaffirm certain aspects of my position (Le Parc 1968a: 229).
\end{abstract}

Le Parc was not the only one changed by the social transformations experienced in Latin America. Due to the significant participation of Latin American artists in the configuration of the Parisian neo-avant-garde, the references to this geopolitical space and its revolutionary movements grew in importance and had a direct impact on the claims of May' 68 . Not only was their collaboration in the mentioned Popular Workshops vital, but also other belligerent artistic actions; for example, during the occupation of the Maison d'Argentine in the Cité Internationale Universitaire de Paris, where some of today's most well-known Latin American artists such as Antonio Seguí, Julio Le Parc, Roberto Matta, Armando Durante, Hugo Demarco, Copi, Alicia Penalba, Rómulo Maccio or Luis Tomasello participated (Barreiro-López, 2009b).

A great many artists, intellectuals and students became fascinated by the resistance movement(s) that had developed all along the southern hemisphere since groups of guerrilleros lead by Fidel Castro dismantled Fulgencio's Batista dictatorship in 1959. Such a fight had multiplied in other contexts, such as the Dominican Republic, México, Nicaragua, Colombia, Uruguay and Bolivia, and it was not uncommon in Europe during the 1960s to consider all those revolutionary processes as different facets of the Latin American example (or "case"). Taking also other movements as witnesses for the success of (united) inferior forces against a seemingly superior enemy, for example the Vietcong's struggle in Vietnam, anti-imperialist claims gained increasing importance in the Parisian cultural and artistic scene. Firstly, the progressive identification of the workers' struggle with the guerrillas fight became a key factor in the politicization process of the French youth (Plante, 2010: 447). Secondly, and even more importantly, such an equation was a determinant for a (re-)configuration of the artists', intellectuals' and students' political imagery and of the Cold War geography.
As Kristin Ross has shown, the identification of the European youth with the Latin American revolution contributed to a shift in their political perception leading in the revolutionary imagery to a(n) (ideological) replacement of the Soviet Union by the Third World (especially Cuba and Vietnam) (Ross, 2002: 81). Of course, artists and art critics, too, looked towards Latin America, Vietnam and China, finding successful examples for their battle against imperialism.

The revolutionary processes in Cuba and its stance against the hegemonic power of the US had already become a source of inspiration and admiration for the artistic scene in France from the middle of the 60s onwards. Castro, but more importantly Che Guevara, became important symbols for the continuous state of revolution they wanted to bring from Latin America to Europe. From the second half of the 1960s onwards the charismatic Che was massively acclaimed, represented and discussed in journals, posters and artistic actions and his exaltation grew even after his assassination in Bolivia in October 1967 (Opus International, 1967). For some of the artists and intellectuals who would participate in May' 68, a more direct experience provided by the Revolutionary Government of Cuba one year prior would further incite their fascination for the Latin American cause and foster their dis-identification with the ideological-geographical bipolarity of the Cold War.

In 1967 the writer and director of the Cuban newspaper Revolución, Carlos Franqui, and the painter Wifredo Lam — both with solid professional networks in Pariswanted to bring the Parisian Salon de Mai (May Salon) to Havana, and invited a group of French-based artists and intellectuals to the Caribbean country in the name of the Cuban government. Among them were writers and art critics such as Michel Leiris, Peter Weiss, Juan Goytisolo, Jorge Semprúm, Alain Jouffroy, Gérald Gassiot Talabot, Margarita Duras, Maurice Nadeau, Jean-Jacques Lévêque, Michel Ragon and Harald Szeemann, as well as artists such as Eduardo Arroyo, Gudmundur Erró, Wifredo Lam, Roberto Matta, Valerio Adami, Antonio Recalcati, Bernard Rancillac, César Baldaccini and Pierre Alechinsky (Llanes, 2012: 58, 61). Their visit did not just have the aim of planning and organizing that year's edition of the Parisian Salon de Mai under the name Salón de Mayo in Havana, but was incited by the grander ambition of establishing a link of exchange with the European continent.

Inaugurated on the 29th of July 1967, the Salón coincided with the Cuban Minister of Foreign Affairs Raúl Roa stressing during the vernissage the "increasing of the guerrilla's warfare in Latin America" (Roa, 1967: 1), ${ }^{9}$ a demonstration of sympathy against oppression that was actually in the spirit of the Salon, which had been founded in 1943 during the Second World War within the French resistance movement against Fascism. More than 100 artists and intellectuals of the "French" delegation (of international members), who had been invited to stay for several days, were supposed to paint and meet with the population. ${ }^{10}$ The Cuban Minister of Education, José Lla- 
nusa, stated that they were provided with the opportunity "to work wherever they wished", expressing the hope "that they would experience new vistas as their project developed in conjunction with workers and students who were transforming Cuban society" (quoted in Stokes Sims, 2002: 155). Hence, the guests travelled the island to meet the cultural and working class of Cuba. Even if monitored by the government, the joining of Frenchbased artists and intellectuals and their meetings with their counterparts, revolutionaries, "guerrilleros" and ordinary people during their stay were regarded as fundamental experiences by all sides.

The participation of the intellectual "European elites" in the Cuban revolutionary-cultural programme was one of the main interests of the government in order to reclaim its independent path, at a time when the consolidation of the revolution was fully achieved (and backed by the Soviet Union) and the country's blockade enforced by the US. However, the different political and ideological models that Cuba and the Soviet Union stood for were clearly manifested visually by the Salón's openness to experimentation and heterogeneity that subverted the orthodoxy of Socialist Realism. The exhibition in Havana gathered more than 196 artworks, the majority of them from classic modern artists of Lam's generation (such as Pablo Picasso, Alexander Calder, René Magritte or Jean Arp) and from younger artists living in Paris from different countries (for example, France, Spain, Turkey, Algeria, Canada, China or different Latin American countries, including Argentina and Cuba). Among the latter were exponents belonging to Figuration Narrative (such as Erró, Arroyo, Rancillac or Aillaud) and Nouvelle Figuration (Jorn and Saura) along with participants of the Nouvelle Tendance and Kinetic Art (such as Le Parc, Yaacov Agam and Vasarely) (VVAA, 1967). The variety of styles presented in Havana represented for the art critic George Boudaille "a precarious but appropriate balance among art movements that at times seem to be in opposition" (quoted in Stokes Sims, 2002: 154). Furthermore, it suited well the ambivalence - and potential of avant-garde experimentation - of the Cuban revolutionary aesthetics (Craven, 2002: 94-114) which had resumed in 1961 with Castro's statement: "with the revolution all, against the revolution, nothing" (Castro, 1961). ${ }^{11}$

The association between the revolutionary ambitions of modern art and its (socio-political) continuation on Cuban soil were stressed continuously. In his speech, Roa underlined the direct connection between the modern basis of the Salón with the revolutionary premises of Cuba's modern state: "If the Salón de Mayo is the universal expression of revolution in painting [...] Cuba embodies today $[. .$.$] the dream and the reality of Revo-$ lution on this side of the Atlantic and a path full of audacities and surprises of revolution within the Revolution" (Roa, 1967: 1). ${ }^{12}$

The artists themselves reaffirmed this connection, taking the opportunity to support the Cuban cause. The exhibition opened with a room dedicated to Cuba, where art- ists showed their commitment to the revolution. It showed very explicit artworks painted in Cuba, such as Bahia Cochinos by Erró or Campesinos by Cesar, some of which were donated for a project of the Galería de Arte Moderno (today held at the Museum of Bellas Artes in Havana). ${ }^{13}$ Along with the artworks manifesting the relation between art, politics and revolution, a glimpse of the revolutionary arsenal that had transformed the island was also shown. Facsimiles of letters (by Fidel Castro and Che Guevara) and a 40-mm air defence gun were physically present in the art show. Furthermore, the exhibition space (virtually) opened up towards an animal show presenting Canadian cattle that had been bought recently (Llanes, 2012, 51f.). Actually, this strange-seeming showcasing to a certain extent put modern art on the same level with the symbolic artefacts of the political, social and economic realities in Cuba.

The organization of the Salón de Mayo, coinciding with the Primera Conferencia de la Organización Latinoamericana de Solidaridad and the Encuentro de la Canción Protesta, helped to give Cuba a particular space within the Cold War configuration, at the very moment of the rival contraposition between the US and the Soviet Union during the international exhibition of 1967 in Montreal. ${ }^{14}$ At that time the official dichotomy of the Cold War had become more and more dissatisfying for leftist artists and intellectuals, who increasingly searched to disconnect from the Moscow-Washington axis, and within the endeavour of disarticulating the simplifying binary polarization of political-ideological concepts, art and culture provided a resourceful ground for argumentation. Franqui and Lam were well aware of that and stressed in their letters the intention to demonstrate "the triumph of the Cuban revolution through its universal resonance in the cultural and spiritual order" (quoted in Stokes Sims, 2002: 155). In fact, the invited artists and intellectuals experienced Havana's Salón de Mayo as an opportunity to connect with a different kind of Socialism. When the organizers provided "young painters and sculptors" with the chance to "work in a socialist country such as Cuba" (Lam quoted in Stokes Sims, 2002: 155), this opportunity did not just offer a chance to complement their admiration for the Cuban revolution with a direct experience in Havana, but also helped to reconfigure the claims of collectivism that many of them had already assumed in the light of the anti-imperialist struggle.

Artists in communion with revolutionaries and guerrilleros (infatuated with the feeling of total celebration that those days in Havana exuded) were actively involved in Havana's cultural life, not just planning and organizing, but making that year's Salón de Mayo a lively event. They all joined in the creation of a wall painting (called Cuba Colectiva; in honour of the revolution). This painting was the socio-political highlight of the artists' participation in Havana, with approximately 90 people from different backgrounds taking part, among them the artists of the Salon de Mai, Cuban artists and even "guerrilleros" manifesting the commu- 


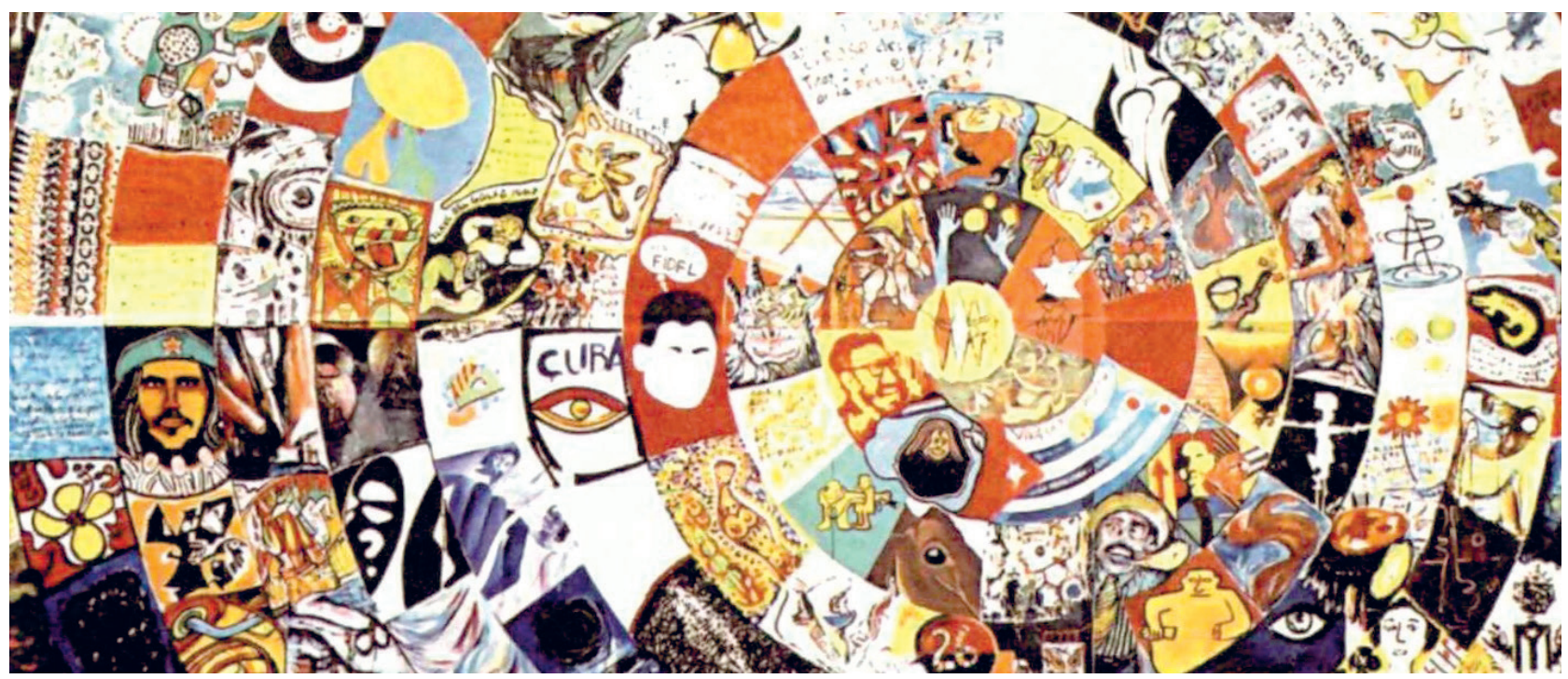

Figure 1: Mural Cuba Colectiva, executed in July 1967 by various artists during the 'Salón de Mayo' in Havana, collection: Museo de Bellas Artes, Havana)

nitarian spirit of the revolution (Ameline, 2008: 121123; Llanes, 2012: 77-80). It depicted a spiral (like a Juego de la Oca 'game of the goose') in which each participant received one supposedly arbitrary spot (even though the most recognized artists would eventually receive the central and best visible lots). Starting with Wifredo Lam's syncretic figuration, the spiral presented a combination of visual and textual references in heterogeneous styles. Providing a combination of individual expressions (each on the respective slots of the painting) in collective collaboration (in terms of an indivisible art piece), Cuba Colectiva challenged the praise of the (bourgeois conception of an) individual production by the West as well as the orthodoxy of the Soviet Union's Socialist Realism. The participants were well aware of this stance, and Eduardo Arroyo and other intellectuals confessed: "It has been a real, total spectacle where for once small individual irritations did not manifest and where for the first time the sacrosanct gestures of the Occidental artist did not show up" (Arroyo, 1967); ${ }^{15}$ and Franqui saw in the wall painting socialist art, regarding it an expression of "collective art [...] an art of liberty, of revolution, imaginative, convulsive, revolutionary, popular ..." (Franqui quoted in Stokes Sims, 2002: 156).

The contact with the Cuban government and the experiences in Havana convinced all participants in situ of the necessity of revolutionary action, the importance of culture in this process and the remarkable capacity that collectivization and participation could have in it. The invited artists and intellectuals wrote a collective manifesto confirming: "The artists and intellectuals who sign this document perceived in Cuba how close the relationship between culture and revolution is" (Leiris et al., 1967: 33). They noticed with admiration how Cuban people "brought literally poetry to the street" (Leiris et al., 1967:
33) ${ }^{16}$ desacralizing the artistic moment, joining the argument that GRAV and the Salon de la Jeune Peinture had used before. The declaration was written in support of Havana's Cultural Congress, a major cultural and political event planned for January 1968. It intended to gather intellectuals, scientists and artists and have them discuss the problems of the Third World without forgetting to stress the necessity of an anti-imperialist stance against the US government for such an undertaking (VVAA, 1968b).

The manifesto was published in an issue of the French avant-garde journal Opus International —a contemporary art magazine edited by Alain Jouffroy, Gérald Gassiot Talabot, Jean Clarence Lambert, Jean-Jacques Lévêque and Raoul-Jean Moulin - that dedicated several pages to the visit in Havana. This journal disseminated the Cuban experience in the French capital in very optimistic and positive terms. Already with its cover by the graphic artist Roman Cieslewicz, an appropriation of Korda's iconic photograph of Che re-elaborated with Pop Art strategies and showing the slogan "Che si" (Che, yes) as its face, the issue showed visually the conviction of the editorial board that "the needle of history had been displaced to Cuba" (Opus International, 1967: 13). ${ }^{17}$

Seeming like a confirmation of this idea, some months after the publishing of this issue of Opus International, on the 4th of January 1968, the Congreso Cultural de La Habana, Reunión de intelectuales de todo el mundo sobre problemas de Asia, África y América Latina [Cultural Congress of Havana, Meeting of intellectuals around the world about issues of Asia, Africa and Latin America] opened with almost 500 participants, among them Jouffroy and some other former guests of the Salón de Mayo (among them Antonio Saura, Asger Jorn, Michel Leiris and Roberto Matta) (VVAA, 1968b). ${ }^{18}$ The event aimed to go beyond the arts, integrating a debate about the Third 


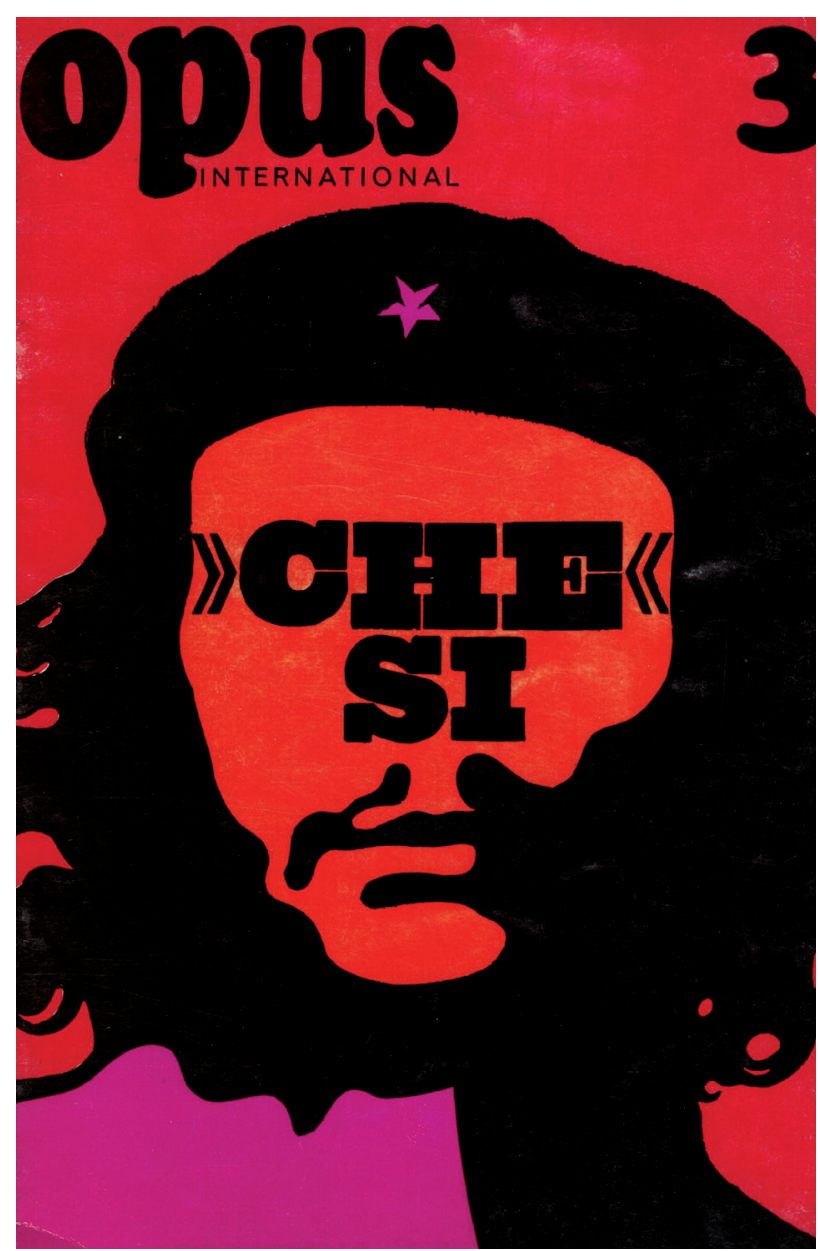

Figure 2: Title page of the journal Opus International by Roman Cieslewicz, no 3, 1967

World, the autonomy from Soviet and Chinese directions with an anti-imperialist agenda that implied "the imperative duty of the intellectuals" to resist and to support the "fight of national liberalisation and social emancipation of the people of Asia, Africa and Latin America and the fight against imperialism" (VVAA, 1968a; Acosta Batista 2013). It was not left to uncertainty that the commitment of the intellectuals "must be reflected in taking position against the politics of cultural colonisation of the USA" (VVAA, 1968a). ${ }^{19}$

This anti-imperialist commitment integrated the artistic world and the avant-garde movements, manifesting the ambition to find a differentiated path from the Soviet guidelines. The second sub-commission of the fifth commission of the Congress ratified the role of the avantgarde in the anti-imperialist struggle and in the socialist society that the participants were aiming to build from Cuba. If the text declared that "the action of the avantgarde should be always informed by a clear political perspective" (VVAA, 1968b), it also underlined that its experimentation and creative freedom were untouchable. ${ }^{20}$ This was an opinion shared at the start of the 1960s by different Communist intellectuals, for example the philosopher Adolfo Sánchez Vázquez, himself a participant at the event (Sánchez Vázquez, 1968). Somehow it even seemed to be contemplated by Castro himself in his closing remarks, where he defended in the spirit of unity that the event pretended to emanate - and that would be crushed just 7 months later with Cuba's support of the Russian invasion of Prague - a more flexible comprehension of Marxism, stating that "it cannot be something as anti-Marxist that the petrification of ideas. There are some ideas used in the name of Marxism that seem real fossils" (Castro, 1968). ${ }^{21}$

The comprehension of the avant-garde as anti-imperialist, political but experimental tended to seek a direct confrontation with the hegemonic cultural policies of the US and the formalist rhetoric of modern art and at the same time with the official Soviet dismissal of avantgarde expressions for its decadent and bourgeois character. Visual examples of this conception in which the avant-garde could nevertheless be part of a socialist programme were provided with Cuba Colectiva [see Fig. 1], created during the Salón, and the lively gestures of Jorn and Saura in several wall paintings at the Oficina del Congreso de Estado, created during the Congreso Cultural (Acosta Batista, 2013). Such experiences and the conclusions of the Havana Congress could not be more appealing to the 1968 Parisian community. Jouffroy was one of the art critics who, supporting the necessity of revolution, most clearly argued for the central place that Cuba's experience could have for European artists. Well-rooted in the legacy of Surrealism, he found in Cuba an opportunity to conciliate avant-garde and revolution and, not so far from André Breton's and Leon Trosky's call "Towards a free and revolutionary art" in 1938, saw:

a new cultural and historical reality through which the individual unconscious is for the first time in direct dialogue with the collective political conscious [...] where hope for a reconciliation of the subversive imagination and revolutionary political reason became a reality (quoted in Stokes Sims, 2002: 156).

\section{CULTURAL GUERRILLA: COMMUNALLY DESTABILIZING THE (BALANCE OF) POWER?}

With the climate of tension and protest growing that destabilized the order in '68, artists and intellectuals in Latin America as well as in Europe were called by different personalities of the artistic scene to join a general Cultural Guerrilla in order to confront imperialism, power abuses and dictatorships. Already in 1967 some voices could be heard that regarded Guerrilla Warfare as a useful battle strategy for the cultural world. For example, from Italy while Umberto Eco argued for Semiological Guerrilla Warfare in order to counteract the imperializing forces of the communication society (Eco, 1967), Germano Celant appropriated this tactic in his first manifesto of Arte (Cullinan, 2008), depicting an 
"artist that stops being exploited for becoming a guerrillero" (Celant, 1999: 100). ${ }^{22}$ However, it was not until 1968 when guerrilla demands multiplied in the cultural world.

From the dais of the Cultural Congress in Havana, Roberto Matta called for a cultural guerrilla "in all fields of subversive thinking and imagination" (Matta quoted in Jouffroy, 1968a: 86). ${ }^{23}$ From Paris, Julio Le Parc did the same in the French magazine Robho, linking art, revolution and participation. He called for:

organizing a sort of cultural guerrilla warfare against the current state of things, highlighting contradictions, create situations in which people recover their ability to bring about change. Fight against every tendency towards the stable, the durable, and the definitive, everything that increases a state of dependency, apathy, and myths - and other mental patterns born of a conditioning that colludes with the structures in power (Le Parc, 1968a: 231).

Through participation, citizens might abandon their passive attitude, becoming active agents in the social field. Discovering that their actions within society could bring changes, they would eventually become a constructive part of the desired transformation of the capitalist system that was greatly based on the economical profit and the imperialist policies of the USA. Such claims reverberated from the Parisian Salon de la Jeune Peinture as well as the journal Opus International, spearheaded by the art critic Alain Jouffroy (Jouffroy, 1968a). Taking action collectively would then become under the name "Cultural Guerrilla" a general strategy of opposition and confrontation with the institutional power, responding to Ernesto Che Guevara's urgency to create "two, three ... a lot of Vietnam" when he was organizing guerrilla troops in Bolivia in 1967 (Guevara, 1967). ${ }^{24}$

Calls to action and to take arms multiplied during May '68. Pamphlets that were distributed in the streets incited readers to guerrilla warfare and to violence: "This call for violence is the updating of the trajectory that leads from the thought to the pavement. WE HAVE TO ARM OURSELVES!" (reproduced in Opus Internation$a l, 1968: 17) .{ }^{25}$ Such calls show well that violence was acclaimed by the revolutionaries of ' 68 in general and became, in their eyes, a necessity for the aspired social transformation.

At the same time, art had become an alternative way of fighting and of carrying out the revolution that students, workers, artists and intellectuals demanded and were looking for. When students armed themselves with paving stones and dismantled Boulevard SaintMichel, artists did the same with their artistic tools, seeking the destruction of the boundaries between the artistic and the socio-political sphere. In this struggle -which was leading the "enrages" to take institutional places and to fiercely resist the law enforcement- they eventually left their workshops to join in the protest movement, becoming active agents of the May events.
The artist Gérard Fromanger recalls that time later with nostalgic words:

Artists [...] don't paint anymore because reality is more powerful than all their inventions. Of course, they become politically active, me in the first place. We create the Ateliers Populaires des Beaux Arts and we make posters. All the country is on strike and we never worked so hard in our lives. We are finally needed (Fromanger, 1998: 43). ${ }^{26}$

Cultural Guerrilla became the strategy that conveyed the urges of action, collectivization and participation. This crystallized in the collective production of posters and wall paintings that became effective tools of the revolutionary forces during the May revolts in several parts of Paris. In the eyes of the artists of that time, it was their role to incite people to take action in their social and political environment. In the Ateliers Populaires, artists actively called for the participation of the workers, students, intellectuals and ordinary people in the collective creation of the affiches (posters). They understood their work as a political mission that had to go beyond the traditional artistic values.

The capacity of the image for the transmission of the political message became a necessity for participation in the social struggle, especially when the media's coverage of the May events was greatly censored in France (Scott, 2008). Whereas silk-screen printing allowed rapid production, a figurative and direct language was used to facilitate the readability of the revolutionary messages. Together with the dissemination of the posters all over the city, the multiplication of messages on the streets helped to reach the audience. One of their inspirations deriving from Maoist Dazibao posters has been pointed out recently (Scott, 2008: 11), but their connection with the Cuban context seems relevant as well. During the 1960s poster production using the silk-screen technique had been strongly developed and the artists visiting Havana were well exposed to the displacement from the advertisement role that this media had transforming the "public space as locus for political debate" (Craven, 2002: 94; Llanes, 2012: 62). Adding this link, one could say that not only did the experiences of revolutionary culture, collective action, participative creation and anti-imperialism in Cuba become one of the justifications for artistic activism during May, but also the idea of bringing poetry and art to the streets was taken literally and implemented with technical and artistic means that were well developed in that Caribbean state.

Be that as it may, the posters of the Ateliers Populaires incited revolutionary actions and brought art, poetry and political messages to the walls of the city. During May and June they insisted constantly on the idea of participation, demanding, for example, to "Participer dans la lutte du people" ("Participate in the peoples' battle") and announcing "Les élèves de Beaux Arts invitent les travailleurs à venir discuter avec eux" ("The students of Fine Arts invite the workers to come and discuss with them"); 
after all, in the Ateliers Populaires themselves, the collaboration between artists, students and workers was following the same principles. ${ }^{27}$ Then, convinced by the necessity of collaboration between artists and working class, the participants of the politically motivated exposition Une salle rouge pour Vietnam even brought their paintings to Belfort and Bourg-en-Bresse. They exhibited the artworks in the streets near the Alsthom and Berliet factories in order to incite their workers to join the battle against imperialism (Ameline, 2008). These examples show that participation and collaboration were general claims that became part of the ideology of May. The central idea of collectivism, for example, also becomes visible on a famous May poster (by Julio Le Parc and other artists of the Ateliers Populaires) showing the silhouettes of six men, starting with one worker holding a wrench and ending with another raising the left fist, united as one body with the slogan, "Nous sommes le pouvoir" ("We are the power"

Whereas the artists of the Ateliers Populaires worked together conveying students', artists' and workers' claims, in the Maison d'Argentine at the Cité Internationale Universitaire de Paris they developed a whole artistic programme directly connected to the "Latin American cause". In collaboration with the Comité d'occupation (Occupation committee) - created to coordinate the Maison during its occupation - the participant artists organized political, cultural and artistic activities that were hosted at the house as a protest against the Ongania's "Junta Militar" and the "permanent violence that the existence of [the Argentinean house] entails" (Comité d'Ocuppation, 1968). ${ }^{28}$ This included exhibitions, the creation of installations and collective artworks as well as their participation in debates. One of their actions was the creation of a - today disappeared-collective wall painting by the Argentinean and Chilean artists Antonio Seguí and Roberto Matta in the communal living room of the house. This artwork was painted collectively following the principles of immediacy, rapidity and expression of the May posters. It was a political attack against the military regime that had been established in Argentina with a coup d'état in 1966. Combining the visual identities of both artists, it showed the dictator Juan Carlos Onganía depicted as a military general falling ridiculously off the horse and losing thereby all of his authority. Next to him, one could see a representation of a half-naked woman recalling the Delacroix "liberty" that seemed to open the way to freedom (Barreiro-López, 2009b).

Like the posters that covered the walls of Paris, the painting responded to the call for protestation and criticism that ruled the '68-generation, as Jean Paul Sartre observed from the tribune of Nouvel Observateur (Sartre, 1968). This protest spirit that evolved exponentially between 1966 and 1968 was considered a requirement for intellectuals and artists of the Left and was taken as principle of action and participation by those involved in the May events. In this ideological battle, paintings were understood as weapons in the field of culture

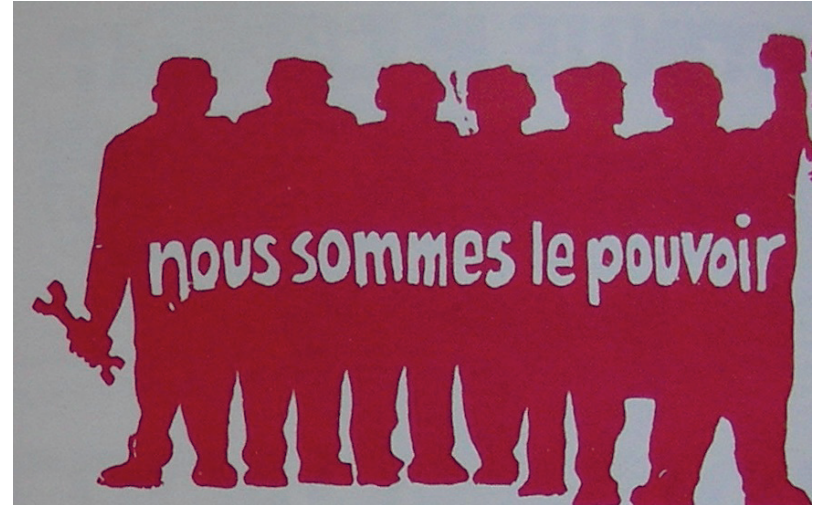

Figure 3: Atelier Populaire (Julio Le Parc and others) La lutte continue, May Poster, 21 May 1968

against a bourgeois society, responding to the key principle "One painting of protest is worth a grenade or a gun" (Gassiot Talabot, 1967: 15). ${ }^{29}$

This was a shared belief in the Parisian artistic scene of '68. Collectivization and, as the examples shown here prove, participation had become an important means to achieve an active position for artists. When the French writer and art critic Michel Troche had written in 1967 that a painting had to lose its contemplative character and focus on the connection with society (Troche, 1967), Jean Clay, even if avoiding the word "politics", argued on the pages of Robho against the harmless and inoffensive artist, asking for integrating art at "the heart of social reality" (Plante, 2010: 453). The revolutionary spring inflamed Parisian artistic circles so much that in June, Jouffroy would even state, "revolution itself has become the only expression of culture [...] to disrupt with the dictatorship of the consumer society" (Jouffroy, 1968b: 10). ${ }^{30}$

Despite this enthusiastic statement, later that month it became clear that the end of the (intended) revolution had already begun. The loss of unity between students, workers, intellectuals and artists and Charles De Gaulle winning the elections by the end of June were hard blows for the committed contestants. Furthermore, Cuba's endorsement of the Soviets' brutal Prague Invasion on the 20th of August (and the subsequent imposition of a Stalinist order in the island) retrospectively even seemed to compromise the actions of the Cultural Guerrilla. After all, Cuba had served as a major reference for the political battle in Europe and Castro's capitulation eventually left the cultural contestants with a bitter aftertaste, even if the revolutionary input continued to be demanded in the Parisian scene.

It seems almost as if Le Parc's call for a Cultural Guerrilla warfare also contained - as the question mark that followed the title of the manifesto seemed to indicate - the possibility of such an outcome. Nevertheless, he had not lost hope, and one month after the political defeat (in August 1968) he continued to encourage an active involvement of the artists in society "to carry out (as in May) a genuine devaluation of myths, myths that 
those in power use to maintain their hegemony" (Le Parc, 1968b: 145). The artists of the Salon de la Jeune Peinture (greatly involved in the May events) would also vote for a continuous belligerent role of art, stressing: "In the battle against bourgeois society we want to fight in the field of culture with our own particular means turning the Salon de la Jeune Peinture in an instrument of ideological fight" (Salon de la Jeune Peinture, 1969). ${ }^{31}$ This continuous belief in the emancipatory power of the arts in the social sphere (throughout participation, collectivism) would survive the washout that summer ' 68 would bring.

$$
* * *
$$

Even though its importance would diminish after 1968, Cultural Guerrilla was a useful concept for organizing the artistic actions that aimed to destabilize the cultural and social system and gained momentum within the European artistic scene of the 1960s. Taking the example of May ' 68 in Paris, action in the artistic sphere was considered part of a general revolutionary process for the struggle against imperialism that had important predecessors and examples in the Latin American, Vietnamese and Chinese context. The participation of Latin American artists and intellectuals in the Parisian events might be seen as a certain transatlantic consistency. However, this is not the only connection, as Cuba and the revolutionary processes of Latin America were perceived as general models by the European youth.

In the French capital, the possibility of experiencing in situ the revolutionary achievements in Havana that opened up for many Paris-based artists and intellectuals during 1967 and 1968 contributed to consolidate the principles of collectivization, participation and socio-political action that had been developed within the artistic practices during the 1960s. The disgust of artists and art critics with the French cultural policies, constantly manifested for example in the journal Opus International ${ }^{32}$ from its first issue in 1966 onwards, was the origin of a search for alternatives that artists and critics undertook in the second half of the 1960s. After they had turned their eyes towards Latin America, the Cuban experience described here seemed to confirm their hopes that the creation of a different world was possible. It also encouraged them in their faith that a different (and better) kind of culture could emerge from the exhausted European centres, such as Paris. From that transatlantic connection came a driving force that was considered to be able to transform the Western culture. Naturally, such a venture was idealistic and (almost) utopian, implying, as Alain Jouffroy mentioned, that:

$[\ldots]$ the day is maybe close when the European intellectual revolutionaries [...] will be able to define themselves in connection with Cuba and Latin-America, at the same time that the Latin-Americans will be able to define themselves in connection with Europe and when this day comes the conditions will be pro- pitious to blow-off and knock over the myth of the supremacy of the Western bourgeois culture (Jouffroy, 1967: 30). ${ }^{33}$

The force of that thought that wanted to "blow-off and knock over" Western culture became clearly visible with the calls for a Cultural Guerrilla from Paris, Cuba and Italy that turned into reality during 1968.

The activism of artists and intellectuals consciously attempted to draft another Cold War geography, introducing new players in order to overcome the dichotomist opposition between the West and the East. Resisting the hegemonic forces of the modernist canon imposed by the cultural agents of the USA and at the same time confronting the official Soviet aesthetic rhetoric established by Moscow, the experimental artistic practices that called for a Cultural Guerrilla and developed within the transatlantic axis entered a proactive dialogue with dissident social and political forces. This means that art and vanguard movements did not just interfere with the representational attitudes and monolithic division of the world imposed by the US and the Soviet Union during the Cold War; they were creating new cultural and political imageries that introduced the political and revolutionary agenda of Latin America's anti-imperialist movements.

This paper is a result of the research project of my Ramón y Cajal contract (RYC-2012-11702) financed by the Mineco, as well as the research projects: "Modernidad(es) Descentralizada(s): Arte, politica y contracultura en el eje trasatlántico durante la Guerra Fría" (ref. HAR201453834-P), "Tras la República: redes y caminos de ida y vuelta en el arte español desde 1931" (ref. HAR 2011-25864) and Art, Glogalització, Interculturalidad (2014SGR1050). I would like to thank Tobias Locker, Sara Brunton and the peer-reviewers for their comments and corrections of this article.

\section{NOTES}

1. "Una pintura] es un instrument de guerra, de ataque y defensa frente al enemigo".

2. I am using collectivization and participation as intertwined terms regarding specific artistic practices that were developed in the 1960s, which — although differing regarding their plastic expressions (geometrical abstraction, figuration, kinetic art, etc.) - were all defined by communal authorship and a leftist political agenda. Collectivization implied the organization of artists in groups and the collaborative creation of artworks and manifestos. For an analysis on collectivization, see Galimberti (2013) and Hillings (2004: 49-75).

3 . Some of the artists belonging to these movements and involved in the events of May ' 68 were Pierre Alechinsky, Karel Appel, Henri Cueco, Gérard Fromanger, Hugo Demarco, Julio Le Parc, Eduardo Arroyo, Jack Vanarsky, Antonio Seguí, Bernard Rancillac, Gilles Aillaud and Roberto Matta.

4. "Constituyendo una fuerza que en definitiva retrasa el avance de la Sociedad".

5. This connection between New Tendencies and the Non-Aligned movement was put forward at the international conference "Postwar. Art between the Atlantic and the Pacific" (Haus der Kunst, 21-24 May 2014) by Armin Medosh in his paper "NonAligned Modernism - the international network and art 
movement New Tendencies (first phase, 1961-1965)" as well as Paula Barreiro López' and Jacopo Galimberti's contribution, "Southern Networks. The Alternative Modernism of the San Marino Biennale and the Convegno internazionale artisti, critici e studiosi d'arte" (conferences available online http://www. youtube.com/watch?v=HwUozqcGsg4).

6. "Certains d'entre nous voudraient le qualifier de socialiste. Il est en tout cas social."

7. González Robles did not support groups, but was nevertheless interested to bring the members of Equipo 57 to the Biennial of Sao Paulo 1961, under the condition that they participated as individual artists. As this was against their artistic and ethical principles, they refused and in consequence never did exhibit at a Spanish pavilion of the Venice and Sao Paulo Biennials during the Franco regime. When Robles had brought the group El Paso to Venice in 1958, its members had exhibited as individual artists without mentioning their affiliation (Barreiro-López, 2009a: 133-134)

8. According to the art critic Gérald Gassiot-Talabot, this artwork caused the rage of the Spanish government, which used all its diplomatic skills to force its censorship (Gassiot Talabot, 1982: 9). The painting was censored under article no. 3 of the Biennial that codified the possibility of exclusion of artworks that could be considered an offence to moral, institutions, religion and national feelings. Even though this account most likely corresponds with the actual events, the documentation of the artwork's censorship in the archives of the Paris Biennial does not mention the Spanish government. Also, during extensive research in the archives of the Spanish Ministry of Foreign Affairs, no proof of the governmental intervention could be found.

9. "El crecimiento de la guerra de guerrilas en América Latina".

10. Among them Jacqueline Seltz e Yvon Thaillandier (members of the Salon's organization as well as Gaston Diehl, its president); artists Edouard Pignon, Eduardo Arroyo, Jean Tinguely, Antonio Recalcati, Bernard Rancillac, Gudmundur Erró, César Baldaccini, Lourdes de Castro, Phillipe Hiquily y Valerio Adami; writers and art critics such as Michel Leiris, Peter Weiss, Harry Mulish, Juan Goytisolo Jorge Semprú, Harald Szeemann, Gérarld Gassiot-Talabot and Alain Jouffroy.

11. "Con la revolución todo, contra la revolución nada".

12. "Si el Salón de Mayo es la expresión universal de la revolución de la pintura [...] Cuba encarna hoy, [...] el sueño y la realidad de la Revolución aquende el Atlántico y el camino repleto de audacias y sorpresas de la revolución dentro de la Revolución. (...)".

13. Artists donating arworks were: Corneille (grupo CoBra), Albert Bitran, Eduardo Arroyo, Bernard Rancillac, René Bertholo, Lourdes de Castro, Valerio Adami, César Aldaccini, Mark de Rosny, Ansgar Elde, Irene Domínguez, Philippe Hiquily, Paul Robeyrolle, Agustín Cárdenas, Leonardo Delfino, Piotr Kowalski and Gudmundur Erró (Acosta Batista, 2013: 37).

14. This "third way" was even reinforced by Cuba's presence in Montreal with a vanguard pavillion designed by Baroni, Garatti and Da Costa, which consisted of various geometrical modules emphasizing a constructivist and rational language. The exhibition presented the economic, industrial, educational cultural and social developments that had been initiated by the Revolution. It connected the revolutionary achievements with an experimental modernist language that dissociated clearly from the guidelines of official Soviet aesthetics.

15. "Ha sido un verdadero espectáculo total, donde por una vez no se han introducido las pequeñas irritaciones individualistas y donde por primera vez no se han manifestado los sacrosantos gestos gestos del artista Occidental".

16. "Les artistes et les intellectuels soussignés on perçu, À Cuba combien est étroite la liaison entre Culture et Révolution"; "fait littéralement descendre la poésie à la rue". This letter was signed in Cuba on 30 July 1967 by intellectuals, art critics and artist, among them: Wifredo Lam, Alain Jouffroy, Eduardo Arroyo, Messagier, Rebeyrolle, Monory, Roland Penrose, Jorge Semprún, Denys Chevalier, Marguerite Duras, Antonio Recalcati, Gilles Aillaud, Lucio Muñoz, Jorge Camacho and Juan Goytisolo.

17. "L'aiguille historique s'est déplacée à Cuba".
18. Participants were, among others: Julio Cortázar, Roberto Matta, Mario Benedetti, David Alfaro Siqueiros, Adolfo Sánchez Vázquez, Aimé Césaire, Antonio Saura, Jorge Semprún, Max Aub, Blas de Otero, Carlos Barral, Luis Goytisolo, Jules Feiffer, Alain Jouffroy, Michel Leiris, Edouard Pignon, André Pieyre de Mandiargues, Yves Lacoste, Asger Jorn, Roman Karmen, Francesco Rossi and Víctor Vasarely (Acosta Batista, 2013).

19. "Apoyar las luchas de liberación nacional, de emancipación social de todos los pueblos de Asia, África y América Latina, y la lucha del imperialismo, en su centro mismo"; "Este compromiso debe reflejarse en una toma de posición categórica contra la política de colonización cultural de los Estados Unidos".

20. "La actuación de las vanguardias deberá estar siempre informada por una clara perspectiva política".

21. "No puede haber nada más antimarxista que la petrificación de las ideas. Y hay ideas que incluso se esgrimen en nombre del marxismo que parecen verdaderos fósiles".

22. "El artista deja de ser explotado para convertirse en guerrillero".

23. "Dans tous les domaines où la pensée et 1 ' imagination subversives ont un rôle à jouer".

24. "Dos, tres ... muchos Viet-Nam".

25. On the one hand, this referred to "the path from thought to action" (in the streets) and on the other -when "trajectory" was understood in militaristic sense (referring to projectiles) - to the use of "paving stones as weapons". "Cet appel à la violence est 1'actualisation de la trajectoire qui va de la pensée au pavé. ARMONS-NOUS",

26. "Les artistes [...] ne peuvent plus peindre parce que le réel est beaucoup plus puissant que toutes leurs inventions. Naturellement, ils deviennent militants, moi le premier. On crée l'atelier populaire des Beaux-arts et on fait des affiches. Tout le pays est en grève et nous, nous n'avons jamais autant travaillé de notre vie. On est enfin nécessaires".

27. The artist Gérard Fromanger, one of the artists participating at the Atelier Populaire, stated that around ten thousand people "passed through the workshops, of which approximately three hundred were artists" (Scott, 2010: 143).

28. "Terminer avec la violence permanente que signifiait l'existence de ce Pavillon".

29. "Une peinture de contestation valait une grenade ou un fusil".

30. "La révolution elle même est devenue la seule forme de culture [...] pour déjouer les diverses dictatures de la société de consommation".

31. "Dans la lutte contre la société bourgeoise nous entendons combattre sur le terrain de la 'culture' selon nos moyens particuliers en faisant du salon de la Jeune Peinture un instrument de lutte idéologique".

32. The first issue of Opus International (no. 1, April 1967) opens with a survey about the situation of the arts in Paris. Artists, critics and intellectuals who would later support May ' 68 revolts, for example Gérarld Gassiot-Talabot, Alain Jouffroy, GRAV, Le Parc and Arroyo, manifested on its pages their conviction about the cultural decline of Paris.

33. "Le jour est peut-etre proche où les intellectuels révolutionnaires européens [...] pourront se définir par rapport à Cuba et l'Amérique Latine, en même temps que les latino-américains se définiront par rapport à l'Europe et, ce jour-là les conditions seront réunies pour faire éclater et renverser le mythe de la suprématie de la culture bourgeoise occidentale".

\section{REFERENCES}

Acosta Batista, Yaniber (2013) Cuba y la cultura. Primera etapa del proyecto revolucionario internacional: el Salón de Mayo y el Congreso Cultural de La Habana. Master's thesis. Advisor Paula Barreiro-López. Universidad de Salamanca

Ameline, Jean Paul (2008) Figuration Narrative. Galeries Nationales du Grand Palais, cat. exh. Paris.

Arroyo, Eduardo (1967) "Mural Cuba colectiva". Salon de Mayo, Pabellón Cuba, 30 July 1967, Havana. 
Aupetitallot, Yves (1998) GRAV: strategies de participation: 19601968. Centro de Arte Contemporáneo, 7 June-6 September, cat. exh. Grenoble.

Barreiro-López, Paula (2003) "La proyección internacional de la abstracción geométrica en España (1957-1972). Una aproximación". In El arte español fuera de España, coordinated by Cabañas Bravo, Miguel. CSIC, Madrid: 143-154.

Barreiro-López, Paula (2009a) La abstracción geométrica en España 1957-1969. CSIC, Madrid.

Barreiro-López, Paula (2009b) "General! La patria agradecida: Acción y reacción en la Maison de l'Argentine en mayo de 1968". Emsemble, Revista electrónica de la casa de Argentina de París, $n^{\circ}$ 2. http://ensemble.educ.ar/wp-content/uploads/2009/10/c2a1 general-la-patria-agradecida-paula-barreiro-lopez.pdf. [accessed 03/October/2014].

Barreiro-López, Paula (2009c). "La Biennale di San Marino et le convegno di Rimini de 1963: Argan, Restany et Aguilera Cerni vers un art engagé". In Le demi-siècle de Pierre Restany, edited by Leeman, Richard. INHA/Editions des Cendres, Paris: 375-386.

Carrick, Jill (2008) "The Assasination of Marcel Duchamp: Collectivism and Contestation in 1960s France". Oxford Art Journal, 31: $1-25$.

Castro, Fidel (1961) "Palabras a los intelectuales". Havana. http:// www.cuba.cu/gobierno/discursos/1961/esp/f300661e.html. [accessed 29/October/2014]

Castro, Fidel (1968) "Discurso de clausura del Congreso Cultural de La Habana". Pensamiento crítico (La Habana), 12. http:// www.filosofia.org/rev/pch/1968/n12p005.htm [accessed 03/ October/2014].

Celant, Germano (1999 [1967]) "Arte povera: apuntes para una guerrilla”. In Arte povera, edited by Fernández Polanco, Aurora. Nerea, San Sebastián: 99-103.

Celant, Germano (dir.) (1981) Identité italienne. L'art en Italie depuis 1959. Centre Pompidou, cat. exh., Paris.

Cockcroft, Eva (1985 [1974]) "Abstract expressionism, weapon of the Cold War". In Pollock and After. The Critical Debate, edited by Frascina, Francis. Harper \& Row Publishers, New York: 125-134.

Comité d'occupation du pavillon argentin (1968) "Ici nos raisons confirmées par des documents". CIUP, mai 68 (Archivo de la Cité Internationale Universitaire de Paris).

Craven, David (2002) Art and Revolution in Latin America, 1910 1990. Yale University Press, New Haven, CT.

Cullinan, Nicholas (2008) "From Vietnam to Fiat-nam: the Politics of Arte Povera". Octobre, 124: 8-30.

Eco, Umberto (1967) "Para una guerrilla semiológica". In La estrategia de la ilusión, edited by Eco, Umberto. Lumen/de la Flor, Barcelona, 1987. http://old.liccom.edu.uy/bedelia/cursos/semiotica/ textos/eco guerrilla.pdf [accessed 03/November/2014].

Equipo 57 (1993 [1957]) “Contra los salones capillas ...”. In Equipo 57. MNCARS, Madrid: 153-157.

Escuela Experimental de Córdoba (1957) Escuela Experimental de Córdoba en la Sala Negra de Madrid Córdoba, November 1957.

Fromanger, Gérald (1998) "L'art c'est ce qui rend la vie plus intéressante que l'art". Libération, 14 May: 43.

Galimberti, Jacopo (2012) "The N Group and the Operaisti: Art and Class Struggle in the Italian Economic Boom”. Grey Room, 49, Fall: 81-101.

Galimberti, Jacopo (2013) Collective Art: Politics and Authorship in 1960s Western European Art, PhD thesis at the Courtauld Institute (advisor: Sarah Wilson).

Gassiot-Talabot, Gérald (1967) "La Havane: peinture et révolution". Opus International, no 3, Paris, October: 16.

Gassiot Talabot, Gérald (1982) "Les années scandaleuses d'Eduardo Arroyo". Arroyo, Centre George Pompidou: 9.

GRAV (1963) "An end to mystification II". In GRAV: strategies de participation: 1960-1968, cat. exh. Aupetitallot, Yves Grenoble, Centro de Arte Contemporáneo, 7 junio-6 septiembre, 1998: 126-137.

Guevara, Ernesto Che (1967) "Mensaje a la Tricontinental: Crear dos, tres... muchos Viet-Nam, es la consigna”. Tricontinental,
16 de abril de 1967. http://www.filosofia.org/hem/dep/cri/ ri12094.htm [accessed 23/February/2015]

Guilbaut, Serge (1983) How New York Stole the Idea of Modern Art. University of Chicago Press Chicago, IL.

Guilbaut, Serge (2007) "Pinceles, palos, manchas: algunas cuestiones Culturales en Nueva York y París tras la Segunda Guerra Mundial". In Bajo la bomba. El jazz de la guerra de imágenes transatlántica. 1946-1956, cat. exh. Serge Guilbaut, MNCARS/ MACBA, Madrid/Barcelona.

Hillings, Valerie L. (2004) "Concrete territory: geometric art, group formation and self-definition". In Beyond geometry. Experiments in Form, 1940s-70s, cat. exh., Lynn Zelevansky, Los Angeles County Museum of Art, MIT Press.

Hofmann, Tobias (cur.) (2007) Die Neuen Tendenzen. Eine Europäische Künstlerewegung 1961-1973, cat. exh. Museum für Konkrete Kunst, Ingolstadt.

Jouffroy, Alain (1967) "Che si”. Opus International, n 3, Paris, Octobre: 23 .

Jouffroy, Alain (1968a) "La guérilla individuelle". Opus International, $\mathrm{n}^{\mathrm{o}} 5$, Paris, February: 86

Jouffroy, Alain (1968b) "Le monde est aux violents". Opus International, $\mathrm{n}^{\circ}$ 7, Paris, June 1968: 10.

Karl Gerstner (1964) "Qu'est ce que la Nouvelle Tendance". Propositions visuelles du mouvement international Nouvelle Tendance, Musée des Arts Décoratifs, Paris, Palais du Louvre, avrilmai, 1964.

Leiris, Michel, et al. (1967) "Pour le congrès culturel de la Havane". Opus International, $\mathrm{n}^{\mathrm{o}}$ 3, Paris, October, 1967: 33.

Le Parc, Julio (1968a) "Cultural Guerrilla Warfare?", In GRAV: strategies de participation: 1960-1968. Aupetitallot, Yves, cat. exh. Centro de Arte Contemporáneo, 7 junio-6 septiembre, Grenoble, 1998: 229-232. 1998: 229-232.

Le Parc, Julio (1968b) "Demystifying art". In Le Parc lumière, kinetic works. Daros Latinoamerica, Zurich, 4-8 October 2005: 144-149.

Longoni, Ana and Lucena, Daniela (2004) "De cómo el 'júbilo creador' se trastocó en 'desfachatez'. El pasaje de Maldonado y los concretos por el Partido Comunista. 1945-1948'. Políticas de la Memoria, $\mathrm{n}^{\circ} 4$

Llanes, Llilian (2012) Salón de Mayo de París en la Habana, julio 1967. Artecubanoediciones, Habana.

Medosch, Armin (2012) Automation, Cybernation and the Art of New Tendencies (1961-1973). Phd thesis at the Goldsmiths University of London (Advisor: Janis Jefferies and Michael Keith).

Picasso, Pablo (1967) Salon de Mayo. Pabellón Cuba, Havana, 30 July: 1 .

Plante, Isabel (2010) "Les Sud-Américains de Paris. Latin American artist and cultural resistance in Robho Magazine". Third Text, 2: 447.

Plante, Isabel (2011) La multiplicación (y rebellion) de los objetos. Julio Le Parc y la consagración europea del arte cinético. FIAAR - Fundación Espigas, Buenos Aires.

Parent, Francis and Perrot, Raymon (1983) El salon de la Jeune Peinture. Histoire 1950-1983. Imprimeurs Livres, Paris.

Roa, Raúl (1967) "Palabras de apertura del Salón de Mayo". In Salón de Mayo (catálogo), La Habana, Pabellón Cuba, 30 July: 2.

Ross, Kristin (2002) May 68 and its Afterlives. University of Chicago Press, Chicago, IL.

Salon de la Jeune Peinture (1969) "Police et culture. Notes préliminaires pour la prochaine manifestation de la jeune peinture". Bulletin Jeune Peinture, n 4, May: 2.

Sánchez Vázquez, Adolfo (1968) "Vanguardia artística y vanguardia política". Casa de las Américas, La Habana, (marzo abril): 112-115.

Sartre, Jean Paul (1968) "Les bastilles de Raymod Aron”. Le nouvel observateur, $\mathrm{n}^{\circ} 188,19$ June.

Scott, Victoria H.F. (2008) "May 68 and the question of image". Rutgers Arts Review, no 24: 1-17.

Scott, Victoria H.F. (2010) Silk-screens and television screens: Maoism and the posters of May and June 1968 in Paris, Phd 
thesis at the University of British Columbia (Advisor: Tom McDonough)

Stonor Saunders, Frances (2000) Who Paid the Piper? CIA and the Cultural Cold War. Granta Books, London.

Stokes Sims, Lowery (2002) Wifredo Lam and the International Avant-Garde 1923-1982, University of Texas Press, Austin, TX.

Troche, Michel (1967) "Une peinture de contestation est-elle possible?" Opus International, $\mathrm{n}^{\circ}$ 2, July: 85-87.
VVAA (1967) Salón de Mayo (catálogo), La Habana, Pabellón Cuba, 30 July, 1967: 2.

VVAA (1968a) "Llamamiento de La Habana". Vida Universitaria (La Habana), No 209: 25. http://annaillustration.com/archivodeconnie/ [accessed 02/November/2014].

VVAA (1968b) Congreso Cultural de La Habana. Reunión de intelectuales de todo el mundo sobre problemas de Asia, Africa y América Latina. Instituto del Libro, La Habana. 